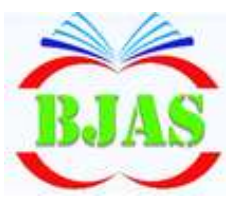

ISSN $1814-5868$
Available online at http://bjas.bajas.edu.iq

https://doi.org/10.37077/25200860.2021.34.2.01

College of Agriculture, University of Basrah

Basrah J. Agric. Sci. 34(2), 1-9, 2021
Basrah Journal of Agricultural Sciences

E-ISSN: 2520-0860

\title{
Minimal Media Strength for In vitro Conservation of Strawberry (Fragaria ananassa) Cultures
}

\author{
Zaid K. Kadhim ${ }^{1}$ \& Muslim A. A. Abdulhussein ${ }^{2 *}$ \\ ${ }^{1}$ Department of Horticulture and Land Scape, College of Agriculture, University of \\ Karbala, Iraq \\ ${ }^{2}$ Department of Horticulture and Land Scape, Faculty of Agriculture, University of Kufa, \\ Iraq
}

*Corresponding author email: muslim.alrubaye@uokufa.edu.iq

Received 15 ${ }^{\text {st }}$ December 2020; Accepted $1^{\text {st }}$ March 2021; Available online 29 October 2021

\begin{abstract}
An experiment for strawberry Fragaria ananassa cv. Festival in vitro conservation of cultures for nine months was studied. Three MS medium strength (full strength MS, $3 / 4 \mathrm{MS}, 1 / 2 \mathrm{MS}$, and $1 / 4 \mathrm{MS}$ ) and the storage period $(3,6$, and 9 months) in slowing down or reducing growth. Results showed a significant effect of the medium salt strength, as the full strength treatment was higher by achieved the highest percentage of viability (survival \%) and storage characteristics of cultures $(\mathrm{N} \%, \mathrm{P} \%$, carbohydrates\%, protein \%) and regeneration ability characteristics (shoots and roots number and length). Three-month storage period achieved the highest rate compared to the nine-month storage period, which recorded the lowest average for the studied characteristics. The full strength treatment for three months storage period realized the highest rate compared to treatment $1 / 4$ strength for the storage period of nine months, which recorded the lowest rate of the studied traits. The application of minimal strength for in vitro conservation allows strawberry cultures to remain viable with a slow growth rate and a significant increase in the storage life of the tissues to nine months.
\end{abstract}

Keywords; In vitro conservation, Minimal medium salt, Slow growth storage, Strawberry.

\section{Introduction}

Strawberry (Fragaria ananassa Duch.) is a perennial herbal fruit plant, with fruits that appreciated for its fragrance, taste and antioxidant capacity resulting from high levels of anthocyanin, and other therapeutic and nutritional properties (Husaini \& Neri, 2016). The cultivation of strawberry has spread in a wide range of geographical areas in the world, as it has extended from tropical and subtropical regions to cold regions, making it adapted to a wide range of climatic conditions as it is grown in about 80 countries (FAO, 2016). In Iraq, strawberry cultivation is still limited and its cultivation is only at the scientific experiment stations, home gardens and some small agricultural areas. The production of strawberry concentrated in the governorates of Mosul, Karbala and Baghdad, 
where production in the country has not reached the required level (Franco, 2009).

Strawberry propagates in two ways: the sexual method, in which the seeds used to produce seedlings that are planted in a permanent place or to generate new varieties. This method is not desirable because it produces plants that are genetically different from the parent plant and therefore percentage of seed germination is low, so that they are propagated by vegetative methods. The strawberry plant's infection with some pathogens, especially viral diseases, result in a decrease in production in quantity and quality, so it is preferable to use the tissue culture method to generate plants free from pathogens for commercial production (Rokosa \& Mikiciuk, 2017).

The difficulty of storing genetic resources in their traditional forms, especially in the form of seeds or runners, the technology of preserving genetic resources via In vitro conservation and super-freezing Cryoconservation have been introduced to application with the assistance of tissue propagation of plants which has been proven to be used as a mean of storage. In vitro conservation of plants cultures, such as strawberries, used for conservation of genetic resources to avoid the loss of many species and varieties by fungal and viral infections or harmful of environmental factors, the possibility of multiplying it without difficulty in tissues culture, the difficulty of preserving its genetic assets in fields and reserves, as well as the conservation cultures by slowing its growth is important in the field of reproduction by preserving it until needed for plantlets production market (Maryam et al., 2014). One of the storage methods is minimal of nutrient medium by reducing the amount of nutrients. This method has been successfully used in storing different vegetatively propagated horticultural plants, such as, Citrus limon (Samarina et al., 2014), Ziziphus jujube Mill (Sota \& Kongjika, 2014), and Prunus webbii (Sota \& Kongjika, 2019).

Because of rare studies on this topic in Iraq, this study aimed to test the possibility of storing strawberry cultures in short- and medium-term storage in laboratories under conditions designed to slow down their growth by reducing of nutrient salts.

\section{Materials \& Methods}

The study was carried out in the Laboratory of Tissue culture, Faculty of Agriculture, University of Kufa during April 2018 to June 2020. Runner segments and runner tips of Strawberry cv Festival was used as explant. Runner tips of festival cultivar were excised with the help of sharp blade and used as sources of meristems. The shoot tips were washed for 2-3 times with sterile distilled water. Surface sterilization was done by dipping the shoot tips into 3\% Clorox $(6 \%$ Sodium hypochlorate) solution with shaking for 15 minutes followed by 3-5 times washing with sterile distilled water. Surface sterilized runner tips that were carefully cultured on MS (Murashige \& Skoog, 1962) medium supplemented with $0.5 \mathrm{mgl}^{-1} \mathrm{BAP}+0.1 \mathrm{mg} . \mathrm{l}^{-}$ ${ }^{1}$ IBA (Mohammed, 2019) in test tube. The cultures were incubated in a growth chamber under $16 / 8 \mathrm{~h}$ light/dark cycle at $25 \pm 1^{\circ} \mathrm{C}$ under illumination with white fluorescent tubes at an intensity of 1000 lux for 3 weeks. The regenerated shoots were carefully removed from the test tubes and transferred to new media for further multiple shoot induction.

After obtaining the sufficient number of multiply shoots, the experiment was carried out to show the effect of the strength of the 
salts of MS nutrient medium (supplemented with $1 \mathrm{mg} .1^{-1} \mathrm{BAP}+0.1 \mathrm{mg} . \mathrm{l}^{-1} \mathrm{IBA}$ according to Mohammed, (2019) as shoot multiplication medium) and the periods of conservation on slowing or reducing culture growth. The MS medium was prepared with different concentrations of the strength of its salts (full strength, $3 / 4,1 / 2,1 / 4)$, and explants were cultured in the form of a small mass with three shoots in 1 litre glass bottles, contained of $100 \mathrm{ml}$ of MS. Cultures were incubated in the growth chamber with light intensity (1000) lux for a period of three, six and nine months). Then the vitality ratio (survival \%), nutrients $(\mathrm{N}, \mathrm{P}, \mathrm{K})$, protein and carbohydrates in shoots on the basis of criteria described by Reed (1992) was evaluated.

After each conservation period (3, 6 and 9 months) cultures reculture in a medium free of growth regulators for two weeks, and then cultured in the medium of multiplication(previously used) by three shoots per glass bottle containing $30 \mathrm{ml}$ of the MS medium and incubated for one month under the same incubation conditions. The ability of the cultures to multiply was evaluated based on growth indicators, as a number of shoots, length of shoots and number of leaves. Then the shoots were transferred to the rooting medium containing the growth regulator IBA at a concentration of $1.0 \mathrm{mg} . \mathrm{l}^{-1}$ (Mohammed, 2019). The cultures were incubated with the same previous lighting conditions, after four weeks of transferring the number and length of roots was counted.

\section{Chemical analysis}

Carbohydrates in cultures were estimated in phenol-sulphuric acid method (Dubois et al., 1956), protein was estimated according to Lowry et al. (1951) and contained of nitrogene, phosphorus, potassium ions estimated using methods described by Kalra (1998).

\section{Experimental design and statistical analysis}

The laboratory conservation of the cultures was carried out as a factorial experiment using a complete random design (CRD) with two factors, the first is the strength of MS salts (full strength, 3/4, 1/2,1/4), the second is storage periods (3, 6 and 9 months) and 10 repetitions per treatment (Al Rawi \& Khalaf Allah 2000). Data were subjected to statistical analysis and averages differences compared according to the Duncan (multi-border) test at the probability level of 0.05 using the program GenStat (VSN International, 2019).

\section{Results}

\section{Cultures vitality}

Data in table (1) and fig. (1) explained that there are no significant differences between conservation periods in survival $\%$, as showed in and fig. (1), and shoots content of $\mathrm{P} \%, \mathrm{~K} \%$, while there is a significant effect on the percentage of shoots $\mathrm{N} \%$, protein, and carbohydrates, where conservation for three months achieved the highest percentage compared to the nine months which achieved the least percentage. Also, there were significant differences between the media with respect to the strength of the salts of the nutrient medium in percentage of vitality, $\mathrm{N} \%, \mathrm{P} \%$, protein, and carbohydrates, as the full-strength treatment achieved the highest percentage compared to the treatment $1 / 4$ salt strength, which recorded the lowest percentages, while, there was no significant effect of the salt strength on the percentage of potassium $\mathrm{K} \%$. 
Table (1): Effect of medium salts strength on the storage characteristics, immediately after laboratory conservation of strawberry cultures.

\begin{tabular}{|c|c|c|c|c|c|c|c|}
\hline \multicolumn{2}{|c|}{ Treatments } & $\begin{array}{c}\text { Survival } \\
\%\end{array}$ & $\mathrm{~N} \%$ & $\mathrm{P} \%$ & $\mathrm{~K} \%$ & $\begin{array}{c}\text { Protein } \\
\%\end{array}$ & $\begin{array}{c}\text { Carbohydrate } \\
\%\end{array}$ \\
\hline \multirow{6}{*}{$\begin{array}{c}\text { Conservation } \\
\text { periods } \\
\text { (month) }\end{array}$} & \multirow{2}{*}{ months 3} & 100 & 3.17 & 0.381 & 3.11 & 19.84 & 20.31 \\
\hline & & $\mathrm{a}$ & $\mathrm{a}$ & $\mathrm{a}$ & $\mathrm{a}$ & $\mathrm{a}$ & $\mathrm{a}$ \\
\hline & \multirow{2}{*}{ months 6} & 91.7 & 2.51 & 0.336 & 2.76 & 15.71 & 17.23 \\
\hline & & $\mathrm{a}$ & $\mathrm{b}$ & $\mathrm{a}$ & $\mathrm{a}$ & $\mathrm{b}$ & $\mathrm{ab}$ \\
\hline & \multirow{2}{*}{ months 9} & 83.3 & 2.04 & 0.259 & 2.43 & 12.73 & 13.69 \\
\hline & & $\mathrm{a}$ & $\mathrm{b}$ & $\mathrm{a}$ & $\mathrm{a}$ & $\mathrm{b}$ & $\mathrm{b}$ \\
\hline \multirow{8}{*}{$\begin{array}{l}\text { MS Media } \\
\text { strength }\end{array}$} & \multirow{2}{*}{$1 / 4 \mathrm{MS}$} & 77.8 & 1.83 & 0.214 & 2.2 & 11.42 & 12.13 \\
\hline & & $\mathrm{b}$ & $\mathrm{b}$ & $\mathrm{b}$ & $\mathrm{a}$ & $\mathrm{b}$ & $\mathrm{c}$ \\
\hline & \multirow{2}{*}{$1 / 2 \mathrm{MS}$} & 88.9 & 2.84 & 0.323 & 3.01 & 17.74 & 19.32 \\
\hline & & $a b$ & $\mathrm{a}$ & $\mathrm{b}$ & $\mathrm{a}$ & $\mathrm{a}$ & $\mathrm{ab}$ \\
\hline & \multirow{2}{*}{$3 / 4 \mathrm{MS}$} & 100 & 2.49 & 0.295 & 2.71 & 15.58 & 15.7 \\
\hline & & $\mathrm{a}$ & $\mathrm{ab}$ & $\mathrm{b}$ & $\mathrm{a}$ & $\mathrm{ab}$ & $\mathrm{bc}$ \\
\hline & \multirow{2}{*}{ Full Strength } & 100 & 3.14 & 0.471 & 3.14 & 19.64 & 21.16 \\
\hline & & $\mathrm{a}$ & $\mathrm{a}$ & $\mathrm{a}$ & $\mathrm{a}$ & $\mathrm{a}$ & $\mathrm{a}$ \\
\hline \multirow{24}{*}{$\begin{array}{l}\text { Conservation } \\
\text { periods x MS } \\
\text { Media strength }\end{array}$} & \multirow{2}{*}{ months+ $1 / 4 \mathrm{MS} 3$} & 100 & 2.53 & 0.264 & 2.73 & 15.8 & 15.17 \\
\hline & & $\mathrm{a}$ & $\mathrm{ab}$ & $\mathrm{abc}$ & $\mathrm{a}$ & $\mathrm{ab}$ & abcd \\
\hline & \multirow{2}{*}{ months+1/2 MS 3} & 100 & 3.26 & 0.379 & 3.15 & 20.37 & 22.7 \\
\hline & & $\mathrm{a}$ & $\mathrm{a}$ & $a b c$ & $\mathrm{a}$ & $\mathrm{a}$ & $\mathrm{a}$ \\
\hline & \multirow{2}{*}{ months+ $3 / 4 \mathrm{MS} 3$} & 100 & 3.38 & 0.361 & 3.21 & 21.11 & 20.26 \\
\hline & & $\mathrm{a}$ & $\mathrm{a}$ & $a b c$ & $\mathrm{a}$ & $\mathrm{a}$ & $\mathrm{ab}$ \\
\hline & \multirow{2}{*}{$\begin{array}{l}\text { months+ MS } 3 \\
\text { Full Strength }\end{array}$} & 100 & 3.53 & 0.522 & 3.34 & 22.08 & 23.1 \\
\hline & & $\mathrm{a}$ & $\mathrm{a}$ & $\mathrm{a}$ & $\mathrm{a}$ & $\mathrm{a}$ & $\mathrm{a}$ \\
\hline & \multirow{2}{*}{ months+ $1 / 4 \mathrm{MS} 6$} & 66.7 & 1.59 & 0.21 & 2 & 9.92 & 12.28 \\
\hline & & $\mathrm{b}$ & $\mathrm{b}$ & $\mathrm{c}$ & $\mathrm{a}$ & $\mathrm{b}$ & bcd \\
\hline & \multirow{2}{*}{ months+ $1 / 2$ MS 6} & 100 & 2.78 & 0.328 & 3 & 17.36 & 18.55 \\
\hline & & $\mathrm{a}$ & $\mathrm{ab}$ & $\mathrm{Abc}$ & $\mathrm{a}$ & $\mathrm{ab}$ & $\mathrm{abc}$ \\
\hline & \multirow{2}{*}{ months+3/4 MS 6} & 100 & 2.43 & 0.292 & 2.92 & 15.17 & 16.38 \\
\hline & & $\mathrm{a}$ & $\mathrm{ab}$ & $\mathrm{Abc}$ & $\mathrm{a}$ & $a b$ & abcd \\
\hline & \multirow{2}{*}{$\begin{array}{l}\text { months+ MS } 6 \\
\text { Full Strength }\end{array}$} & 100 & 3.26 & 0.515 & 3.1 & 20.38 & 21.71 \\
\hline & & $\mathrm{a}$ & $\mathrm{a}$ & $\mathrm{Ab}$ & $\mathrm{a}$ & $\mathrm{a}$ & $\mathrm{a}$ \\
\hline & \multirow{2}{*}{9 months+ $1 / 4 \mathrm{MS}$} & 66.7 & 1.36 & 0.169 & 1.87 & 8.53 & 8.93 \\
\hline & & $\mathrm{b}$ & $\mathrm{b}$ & $\mathrm{c}$ & $\mathrm{a}$ & $\mathrm{b}$ & $\mathrm{d}$ \\
\hline & \multirow{2}{*}{ months+1/2 MS 9} & 66.7 & 2.48 & 0.261 & 2.87 & 15.48 & 16.71 \\
\hline & & $\mathrm{b}$ & $\mathrm{ab}$ & $\mathrm{abc}$ & $\mathrm{a}$ & $\mathrm{ab}$ & abcd \\
\hline & \multirow{2}{*}{ months+ $3 / 4$ MS 9} & 100 & 1.67 & 0.231 & 2.01 & 10.46 & 10.47 \\
\hline & & $\mathrm{a}$ & $\mathrm{b}$ & bc & $\mathrm{a}$ & $\mathrm{b}$ & $\mathrm{cd}$ \\
\hline & months+ MS 9 & 100 & 2.63 & 0.376 & 2.98 & 16.46 & 18.67 \\
\hline & Full Strength & $\mathrm{a}$ & $a b$ & $a b c$ & $\mathrm{a}$ & $\mathrm{ab}$ & $a b c$ \\
\hline
\end{tabular}




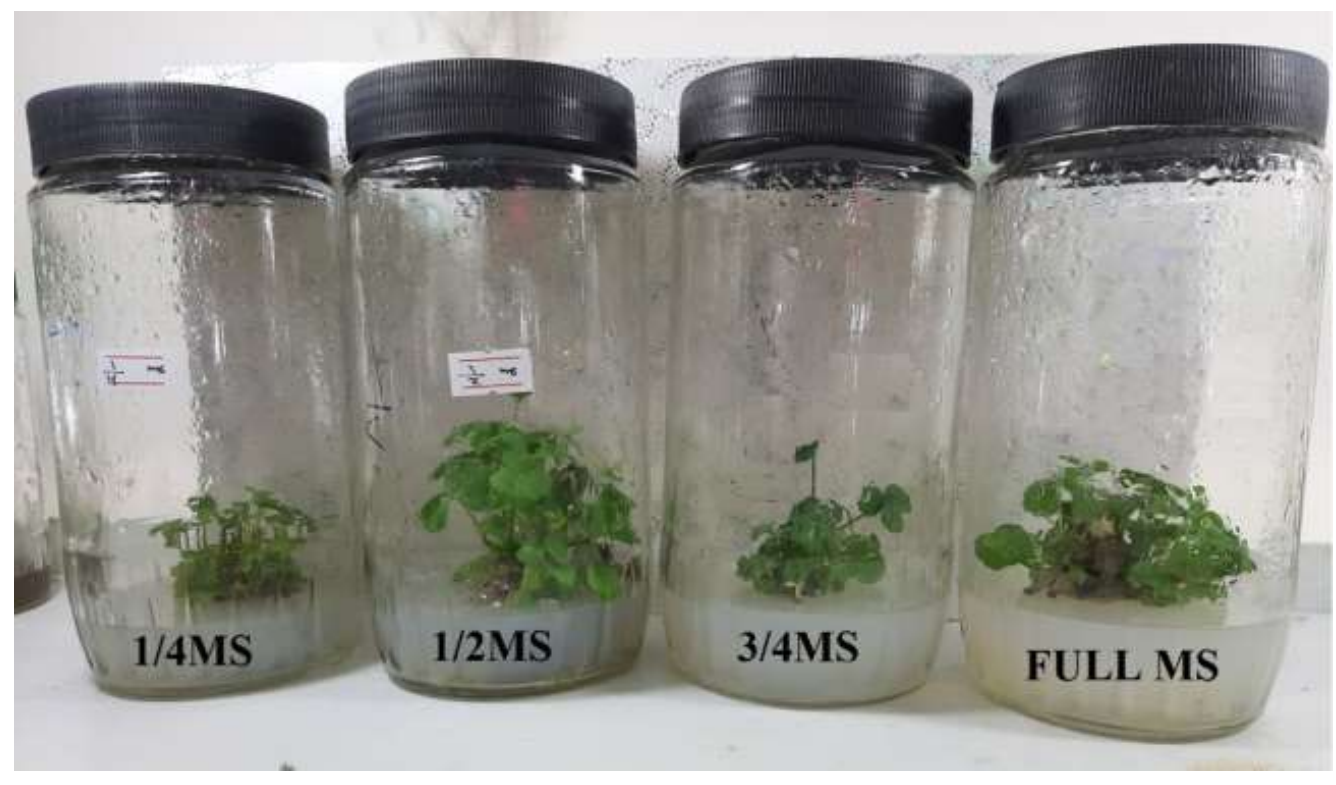

Fig. (1): Strawberry Cultures survival after nine months of in vitro storage.

In addition, there is a significant effect of the interaction between the media strength and storage periods in the percentage of vitality. Storage periods for six and nine months in $1 / 4 \mathrm{MS}$ salt strength achieved the lowest percentage $(66.7 \%)$ compared to the others interference which achieved (100\%), while the intervention treatment (three months + full strength) achieved the highest percentage in which was $3.53 \%, 0.522 \%$, $3.34 \%, 22.08 \%, 23.1 \%$ for $\mathrm{N} \%, \mathrm{P} \%, \mathrm{~K} \%$, protein, and carbohydrates respectively.

\section{Regeneration ability after in vitro conservation}

Table (2) showed that there are significant differences between the periods of conservation on the number of shoots, length of shoots, number of leaves, and number of roots). Three months period of conservation achieved the highest rate of 4.17 shoots, 3.99 $\mathrm{cm}, 4.16$ leaves, 3.04 roots, respectively, compared to nine months conservation period, which achieved the lowest average of 2.87 shoots, $2.73 \mathrm{~cm}, 3.06$ leaves, and 2.24 roots, respectively, while the duration of conservation did not record any significant difference for the length of the roots.

There were significant differences between the media (table 2) in number of shoots, length of shoots, number of leaves, number of roots, and length of roots) as the full strength treatment gave the highest rate of 4.48 shoots, $4.11 \mathrm{~cm}, 4.34$ leaves, 3.12 roots, $4.36 \mathrm{~cm}$, respectively, compared to the $1 / 4 \mathrm{MS}$ salts, which recorded the lowest means (2.67 shoots, $2.47 \mathrm{~cm}, 2.73$ leaves, 1.96 roots, 2.84 $\mathrm{cm})$, respectively.

It is noted from the same table that there is a significant effect of the interaction between the MS strength and storage periods on (number of shoots, length of shoots, number of leaves, number of roots, and length of roots), in which interaction treatment (three months + full strength) is recording the highest rate of 5.33 shoots, $4.78 \mathrm{~cm}, 5.0$ leaves, 3.33 roots, $5.0 \mathrm{~cm}$ respectively, compared to the treatment ( 9 months $+1 / 4 \mathrm{MS}$ ), which scored the lowest rate (2.11 shoots, $2.04 \mathrm{~cm}, 2.29$ leaves, 1.56 roots, $2.43 \mathrm{~cm}$ ) respectively. 
Table (2): Effect of the medium strength on regeneration ability after in vitro conservation of strawberry cultures.

\begin{tabular}{|c|c|c|c|c|c|c|}
\hline \multicolumn{2}{|c|}{ Treatments } & $\begin{array}{l}\text { shoots } \\
\text { Number }\end{array}$ & $\begin{array}{c}\text { shoots } \\
\text { Length }(\mathrm{cm})\end{array}$ & $\begin{array}{c}\text { Leaves } \\
\text { Number }\end{array}$ & $\begin{array}{c}\text { Root } \\
\text { Number }\end{array}$ & $\begin{array}{l}\text { Root Length } \\
\text { (cm) }\end{array}$ \\
\hline \multirow{3}{*}{$\begin{array}{l}\text { Conservation } \\
\text { periods(month) }\end{array}$} & months 3 & $4.17 \mathrm{a}$ & $3.99 \mathrm{a}$ & $4.16 \mathrm{a}$ & $3.04 \mathrm{a}$ & $4.1 \mathrm{a}$ \\
\hline & months 6 & $3.47 \mathrm{ab}$ & $3.5 \mathrm{ab}$ & $3.5 \mathrm{ab}$ & $2.7 \mathrm{ab}$ & $3.6 \mathrm{a}$ \\
\hline & months 9 & $2.87 \mathrm{~b}$ & $2.73 b$ & $3.06 \mathrm{~b}$ & $2.24 b$ & $3.23 \mathrm{a}$ \\
\hline \multirow{4}{*}{$\begin{array}{l}\text { MS Media } \\
\text { strength }\end{array}$} & $1 / 4 \mathrm{MS}$ & $2.67 \mathrm{~b}$ & $2.47 \mathrm{~b}$ & $2.73 b$ & $1.96 \mathrm{~b}$ & $2.84 b$ \\
\hline & $1 / 2 \mathrm{MS}$ & $3.50 \mathrm{~b}$ & $3.60 \mathrm{ab}$ & $3.77 \mathrm{ab}$ & $3.05 \mathrm{a}$ & $3.95 \mathrm{ab}$ \\
\hline & $3 / 4 \mathrm{MS}$ & $3.37 \mathrm{ab}$ & $3.37 \mathrm{a}$ & $3.45 \mathrm{ab}$ & $2.51 \mathrm{ab}$ & $3.41 \mathrm{ab}$ \\
\hline & Full Strength & $4.48 \mathrm{a}$ & $4.11 \mathrm{a}$ & $4.34 \mathrm{a}$ & $3.12 \mathrm{a}$ & $4.36 \mathrm{a}$ \\
\hline \multirow{12}{*}{$\begin{array}{l}\text { Conservation } \\
\text { periods x MS } \\
\text { Media strength }\end{array}$} & $\begin{array}{c}\text { months+ } \\
1 / 4 \mathrm{MS}\end{array}$ & $3.44 \mathrm{abc}$ & $3.14 \mathrm{ab}$ & $3.6 \mathrm{ab}$ & $2.56 \mathrm{ab}$ & $3.38 \mathrm{ab}$ \\
\hline & $\begin{array}{c}\text { months }+1 / 23 \\
\text { MS }\end{array}$ & $3.9 \mathrm{abc}$ & $4.03 \mathrm{ab}$ & $4 \mathrm{ab}$ & $3.16 \mathrm{ab}$ & $4.00 \mathrm{ab}$ \\
\hline & $\begin{array}{c}\text { months+ } 3 \\
3 / 4 \mathrm{MS}\end{array}$ & $4 \mathrm{abc}$ & $4.03 \mathrm{ab}$ & $4.03 \mathrm{ab}$ & $3.11 \mathrm{ab}$ & $4.00 \mathrm{ab}$ \\
\hline & $\begin{array}{c}\text { months+ } 3 \\
\text { MS Full } \\
\text { Strength }\end{array}$ & $5.33 \mathrm{a}$ & $4.78 \mathrm{a}$ & $5.00 \mathrm{a}$ & $3.33 \mathrm{a}$ & $5.00 \mathrm{a}$ \\
\hline & $\begin{array}{c}\text { months+ } \\
1 / 4 \mathrm{MS} \\
\end{array}$ & $2.44 \mathrm{bc}$ & $2.24 \mathrm{~b}$ & $2.3 \mathrm{~b}$ & $1.78 \mathrm{ab}$ & $2.72 \mathrm{ab}$ \\
\hline & $\begin{array}{c}\text { months }+1 / 26 \\
\text { MS }\end{array}$ & $\begin{array}{l}3.44 \\
\mathrm{abc}\end{array}$ & $3.76 \mathrm{ab}$ & $3.83 \mathrm{ab}$ & $3.11 \mathrm{ab}$ & $4.07 \mathrm{ab}$ \\
\hline & $\begin{array}{c}\text { months+ } 6 \\
\text { 3/4 MS }\end{array}$ & $3.56 \mathrm{abc}$ & $3.98 \mathrm{ab}$ & $3.67 \mathrm{ab}$ & $2.78 \mathrm{ab}$ & $3.42 \mathrm{ab}$ \\
\hline & $\begin{array}{c}\text { months+ } 6 \\
\text { MS Full } \\
\text { Strength } \\
\end{array}$ & $4.44 \mathrm{ab}$ & $4.03 \mathrm{ab}$ & $4.21 \mathrm{ab}$ & $3.15 \mathrm{ab}$ & $4.18 \mathrm{ab}$ \\
\hline & $\begin{array}{c}\text { 9months+ } 1 / 4 \\
\text { MS }\end{array}$ & $2.11 \mathrm{c}$ & $2.04 \mathrm{~b}$ & $2.29 \mathrm{~b}$ & $1.56 \mathrm{~b}$ & $2.43 \mathrm{~b}$ \\
\hline & $\begin{array}{c}\text { months }+1 / 29 \\
\text { MS }\end{array}$ & $3.15 \mathrm{bc}$ & $3.27 \mathrm{ab}$ & $3.48 \mathrm{ab}$ & $2.89 \mathrm{ab}$ & $3.79 \mathrm{ab}$ \\
\hline & $\begin{array}{c}\text { months+ 3/4 } 9 \\
\text { MS }\end{array}$ & $2.56 \mathrm{bc}$ & $2.09 \mathrm{~b}$ & $2.65 \mathrm{~B}$ & $1.63 \mathrm{~b}$ & $2.8 \mathrm{ab}$ \\
\hline & $\begin{array}{c}\text { months+ } 9 \\
\text { MS Full } \\
\text { Strength }\end{array}$ & $3.67 \mathrm{abc}$ & $3.53 \mathrm{ab}$ & $3.82 \mathrm{ab}$ & $2.89 \mathrm{ab}$ & $3.89 \mathrm{ab}$ \\
\hline
\end{tabular}




\section{Discussion}

The results of tables (1 and 2) showed a significant effect of the concentration of medium MS salts on the percentage of cultures viability and regeneration ability (shoots multiplication and rooting), these results agreed with what Ahmed et al. (2010), Samarina et al. (2014) and Sota \& Kongjika (2019) who found that the survival $\%$ and shoots multiply decreases with increasing conservation time, but it remained survival.

The medium nutritional status is one of the most important factors that affect the growth of the cultures grown in vitro, because of its importance in providing the nutrients necessary for the growth and development of cultures, since the explants depending on what the medium provides of nutrients (Vinay \& Afroz, 2015). so, the components of the nutrient medium and its physical state is very important and must be determined due to its importance for in plant growth in a specific stage and its subsequent effect later stages of micropropagation. The Medium salt strength is one of the factors most often evaluated in studies related to the in vitro conservation of various plant species (Huang et al., 2014). Several modifications can be made in the MS medium to reduce the growth of plant parts preserved in the laboratory. This involves reducing plant metabolism by increasing the laboratory period of plant growth, without altering the genetic make-up, plant quality, and its ability to multiply and produce new plantlets after storage (Kamińska et al., 2016).

Our results showed that the conservation period has a significant effect on the percentage of cultures vitality in the laboratory to maintain the ability to multiply and rooting, as this effect varied according to the strength of medium, as it was noticed that the conservation period of 3 and 6 months had good results, if compared to the 9-month conservation period, and with the increase in the conservation period to 9 months, the viability percentage and ability to multiply and rooting decreased. These results are in line with what Trejgell et al. (2015) found when storing Senecio macrophyllus shoots in vitro for three and six months.

\section{Conclusion}

Strawberry Cultures can be in vitro conserved successfully for nine months with minimal salt strength of MS medium.

\section{Acknowledgements}

The authors are very much grateful to staff of plant tissue culture Lab, Faculty of Agriculture, University of Kufa for the financial support to this study.

\section{Orcids}

M. A. Abdulhussein:https: http//orcid.org/00000002-9813-0764

\section{References}

Ahmed, M., Anjum, M. A., Shah, A.H., \& Hamid, A. (2010). In vitro conservation of Pyrus germplasm with minimal growth using different temperature regimes. Pakistan Journal of Botany, 42, 1639-1650. http://www.pakbs.org/pjbot/PDFs/42(3)/PJB42(3)1639 .pdf

Al- Rawi, K. M., \& Khalaf Allah A. A. M. (2000). Design and Analysis of Agricultural Experiments. Books House for Printing and Publishing. University of Mosul. 484 pp. (in Arabic).

Dubois, M. K., Crilles, K. A., Hamiltor, J. K., Rebers, D. A., \& Smith, F. (1956). Colorimetric method for determination of sugars and substance. Analytical Chemistry, 28 , 350-365. https://doi.org/10.1021/ac60111a017 


\section{Kadhim \& Abdulhussein / Basrah J. Agric. Sci., 34(2): 1-9, 2021}

FAO, (2016). Food and Agriculture Organization of the United Nations. FAOSTAT agriculture data. http://faostat3.fao.org/download/Q/QC/E. Accessed May 2016.

Franco, S., (2009)

The Production of Strawberries in Iraq. Ministry of Agriculture, Iraq. pp. 1-10. U.S. Agency for International development (USAID).

Huang, H. P., Wang, J., Huang, L. Q., Gao, S. L., Huang, P., \& Wang, D. L. (2014). Germplasm preservation in vitro of Polygonum multiflorum Thunb. Pharmacognosy Magazine, 10, 179-184. http://www.phcog.com/text.asp?2014/10/38/179/13108 3

Husaini, A. M., \& Neri, D. (2016). Strawberry: Growth, development and diseases. CABI Publishing, 315pp. https://doi.org/10.1079/9781780646633.0000

Kamińska, M., Skrzypek, E., Wilmowicz, E. E., Tretyn, A., \& Trejgell, A. (2016). Effect of light conditions and ABA on cold storage and post-storage propagation of Taraxacum pieninicum. Plant Cell, Tissue and Organ Culture, 127, 25-34. https://doi.org/10.1007/s11240-016-1026-1

Kalra, Y. P., (1998). Handbook of Reference Methods for Plant Analysis. Soil and Plant Analysis Council, Inc., CRC Press. FL., 287pp. https://plantstress.com/wpcontent/uploads/2020/03/Handbook_of_Reference_Me thods_for_Plant_Analysis-1998.pdf

Lowry, O. H., Rosebrough, N. J., Farr, A. L., \& Randull, R. J. (1951). Protein measurement with Folin phenol reagent. Journal of Biological Chemistry, 193, 295$297 . \quad$ https://www.jbc.org/article/S00219258(19)52451-6/pdf

Maryam, A., Tariq, A., Chuadhary, S., Azmat, R., Javed, S., \& Khanam, S. (2014). A review: Role of tissue culture (in vitro) techniques in the conservation of rare and endangered species. Pacific Journal of Life Sciences, 2, 93-103.

https://www.academia.edu/7259757

Mohammed, M. H. (2019). Response of strawberry plant Fragaria ananassa Duch to light quality and some growth stimulators in vitro. M. Sc. Thesis. Faculty of Agriculture, University of Kufa, 111pp. (in Arabic).
Murashige, T., \& Skoog, F. (1962). A revised medium for rapid growth and bioassays with tobacco tissue cultures. Physiologia Plantarum, 15, 473- 497. https://doi.org/10.1111/j.1399-3054.1962.tb08052.x

Reed, B. M. (1992). A cold storage of strawberries in vitro: A comparison of three storage systems. Fruit Varieties Journal, 46, 98-102. https://europepmc.org/article/agr/ind92031926

Rokosa, M., \& Mikiciuk, M. (2017). In vitro regeneration of Fragraria plants. Acta Scientiarum Polonorum, Hortorum Cultus, 16, 145-158. http://www.hortorumcultus.actapol.net/volume16/issue 5/16_5_145.pdf

Samarina, L. S., Choudhary, R., Kolomiets, T. M., Abilfazova, Y. S., \& Saran, P. L. (2014). In vitro Conservation Technique for Russian Citrus limon. Agricultural Research, 3, 279-283. https://www.tib.eu/en/search/id/BLSE\%3ARN363052 056

Sota, V., \& Kongjika, E. (2014). Slow growth in vitro conservation of Zizyphus jujuba Mill. Agriculture \& Forestry, 60, 27-37. http://89.188.43.75/agricultforest/2014021803\%20SOTA\%20and\%20KONGJIKA.pdf.

Sota, V., \& Kongjika, E. (2019). Micropropagation and in vitro conservation via slow growth techniques of Prunus webbii (Spach) Vierh: An endangered plant species in Albania. International Journal of Agricultural and Biosystems Engineering, 13, 11, 280283. https://doi.org/10.5281/zenodo.3566425.

Trejgell, A., Kaminska, M., \& Tretyn, A. (2015). In vitro slow growth storage of Senecio macrophyllus shoots. Acta Physiologiae Plantarum, 37, 234. https://doi.org/10.1007/s11738-015-1983-8.

Vinay, S. \& Afroz, A. (2015). Plant Tissue Culture. I K. International Publishing House. 378pp. https://www.waterstones.com/book/plant-tissueculture/vinay-sharma/afroz-alam/9789384588441

VSN International. (2019). GenStat for Windows 12th Edition. VSN International, Hemel Hempstead, UK. 
Kadhim \& Abdulhussein / Basrah J. Agric. Sci., 34(2): 1-9, 2021

\section{تقليل أملاح الوسط الغذائي لخزن زروعات نبات الفراولة خارج الحسم الحي زيد خليل كاظم1 و مسلم عبدعلي عبد الحسين2 \\ 1 قسم البستنة و هندسة الحدائق، كلية الزر اعة، جامعة كربلاء، العر اق \\ 2 قسم البستنة و هندسة الحدائق، كلية الزر اعة، جامعة الكوفة، العراق}

المستخلص: أجريت التجربة لدراسة تأثير الخزن المختبري لزروعات نبات الفراولة لمدة 9,6,3 أثهر المزروعة في الوسط الغذائي MS ذو قوه املاح مختلفة (قوه كامله, 314 القوه, 112 القوه,114 القوه). أظهرت النتائج وجود تأثير معنوي لقوة الوسط في تقليل النمو،

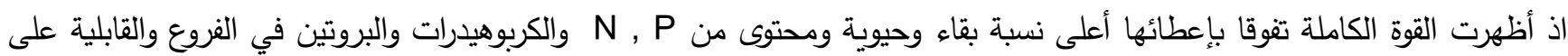
التوليد (استعادة التضاعف والتجذير) المتمثلة في عدد الأفرع والجذور واطوالها. كما ان الخزن الدختبري لمدة 3 اشهر قد أعطى أفضل النتائج للصفات الددروسة وأبدت معاملة الخزن لددة 3 اشهر في وسط كامل القوة تفوقا على المعاملات الاخرى في حين أعطت معاملة الزراعة في 114 قوه الوسط لددة 9 أشهر اقل القيم للصفات المدروسة. ان الزروعات النسيجية للفراولة يمكن خزنها مختبريا بنجاح لددة 9 أشهر دون تأثر حيويتها وقدرتها على التضاعف والتجذير . الكلمات المفتاحية: نبات الفراولة، الخزن المختبري للزروعات النسيجية، تقليل املاح الوسط ، الخزن بتقليل النمو خارج الجسم الحي. 